\title{
Aspek Biologi Pari kekeh (Rhynchobatus sp.) (Rhinidae:Chondrichthyes) Studi Kasus di PPN Brondong, Lamongan
}

\author{
Lara Azidha*, Irwani, Munasik \\ Departemen IImu Kelautan, Fakultas Perikanan dan IImu Kelautan, Universitas Diponegoro \\ JI. Prof. H. Soedarto S.H., Tembalang, Semarang, Jawa Tengah 50275 Indonesia \\ *Corresponding author, e-mail : lara.azidhaa@gmail.com
}

\begin{abstract}
ABSTRAK : Pari kekeh (Rhynchobatus sp.) adalah organisme laut yang tergolong dalam Subkelas Elasmobranchii dan dikelompokkan ke dalam Kelas Chondrichthyes. Pari kekeh sering ditangkap dikarenakan dagingnya memiliki rasa yang enak, Selain itu, sirip Pari kekeh memiliki harga yang mahal di China dan Global. Pari kekeh telah masuk kedalam daftar IUCN red list kategori critically endangered akibat eksploitasi berlebihan. Hal ini apabila terus terjadi maka ketersedian sumber daya Pari kekeh di habitatnya terancam punah. Oleh karena itu, perlu adanya pengaturan agar tidak terjadi eksploitasi berlebihan yang berdampak pada populasi pari kekeh, salah satunya dengan melakukan analisis aspek biologi. Tujuan dari penelitian ini untuk mengetahui hubungan panjang berat, nisbah kelamin, tingkat kematangan gonad, ukuran pertama kali matang gonad dan fekunditas Pari kekeh yang didaratkan di PPN Brondong. Sampel yang digunakan yaitu pari kekeh sebanyak 160 ekor. Penelitian ini menggunakan metode deskriptif dengan mengukur data panjang total dan standar, bobot, pengamatan gonad. Pola pertumbuhan Pari kekeh yaitu allometrik negatif $(b=2,52)$. Nisbah kelamin $=0,625$ (Chi Square) dengan $X$ tabel $=3,975$, maka jumlah Pari jantan dan betina seimbang. Kematangan gonad Pari Rhynchobatus sp. sebesar 53\%. Ukuran pertama kali matang gonad Pari kekeh jantan memiliki panjang total $48,97-49,16 \mathrm{~cm}$ dan Pari kekeh betina memiliki panjang total 95,29-98,60 cm. Nilai fekunditas Pari kekeh berkisar antara 5-16 butir pada kisaran panjang total tubuh $86-114 \mathrm{~cm}$.
\end{abstract}

Kata Kunci : Ikan Pari; Rhynchobatus sp.; Aspek Biologi

\section{The Biological Aspects of Kekeh Stingrays (Rhynchobatus sp.) (Rhinidae:Chondrichthyes) Case Study in PPN Brondong, Lamongan}

ABSTRACT : Kekeh Stingrays (Rhynchobatus sp.) are marine organisms that classified to the Elasmobranchii subclass and grouped into the Chondrichthyes Class. Kekeh Stingrays is often caught because has a good taste. In addition, Kekeh Stingrays fins have a high price in the Stingray and Shark fin trade in China and Global. Kekeh Stingrays has entered into the IUCN red list in the critically endangered category due to overexploitation. If excessive exploitation continues, the availability of Stingray resources in their habitat will be threatened. Therefore, there is a need for control to avoid overexploitation that affects the population of Kekeh Stingrays, one of which is by analyzing the biological aspects. The purpose of this study was to determine the length and weight correlation, sex ratio, gonad maturity level, size of the first gonad maturity, and fecundity of Kekeh Stingray which was landed in PPN Brondong. The samples used were 160 Kekeh Stingrays. This research uses descriptive method by measuring the total and standard length, weight, also gonad observations. The results obtained are the length and weight correlation of Stingray Kekeh which is negative allometric with a value of $b=2.52$. The sex ratio based on Chi Square $(x 2)=0,625$ with $X$ table $=3,975$, that means the number of male and female Stingray is balanced. The value of TKG II and TKG III of Rhinchobatus sp.that is, 53\% is dominated by matured Rays. The first size of gonad maturity for rays was in a range 48,97-49,16 cm, while for female rays was in a range 95,29-98,60 cm. The Value of Kekeh Stingrays's fecundity was around $5-16$ eggs with the total length range is $86-114 \mathrm{~cm}$.

Keywords : Stingrays; Rhynchobatus sp.; Biological Aspects 


\section{PENDAHULUAN}

Kabupaten Lamongan merupakan salah satu Kabupaten di Jawa, yang mempunyai hasil laut cukup melimpah. Hal tersebut dibuktikan dengan pernyataan Yaskun dan Sugiarto (2017), pada tahun 2015 -2017 produksi perikanan tangkap di Perairan Lamongan meningkat hingga mencapai 72.346 ton. Oleh karena itu, di Kabupaten lamongan dibangun pelabuhan perikanan, salah satunya yaitu Pelabuhan Perikanan Nusantara (PPN) Brondong yang merupakan salah satu pelabuhan perikanan tipe B yang ada di Indonesia. Menurut Huda et al. (2015). PPN Brondong ditetapkan menjadi kawasan minapolitan di Jawa Timur berdasarkan surat keputusan Menteri Kelautan dan Perikanan nomor : 32/MEN/2010 tanggal 14 Mei 2010. Hal tersebut membuat PPN Brondong menjadi pusat pendaratan banyak jenis ikan hasil tangkapan nelayan seperti Ikan Tongkol (Euthynnus affinis), Ikan Kakap Merah (Lutjanus campechanus), Ikan Kuniran (Upeneus sulpureus), Layang (Decapterus sp.), jenis ikan demersal pun sering tertangkap seperti contohnya ikan hiu dan pari.

Pari merupakan salah satu sumberdaya perikanan berkelanjutan di Indonesia. Di Indonesia Ikan Pari sering ditemukan di Laut Jawa dan bagian Selatan Pulau Jawa. Lamongan merupakan penghasil Ikan Pari terbesar, produksi perikanan pari di Lamongan khususnya yang didaratkan di PPN Brondong pada periode 2013-2017 telah mencapai 4.787 ton. Salah satu jenis Ikan Pari yang banyak tertangkap yaitu Pari kekeh (Rhynchobatus sp.) (Parmanto,2019). Pari kekeh adalah salah satu jenis dari pari yang memiliki nilai ekonomis tinggi. Bagian dari Pari kekeh yang sering diperjual belikan ialah bagian sirip, di pasaran memiliki harga 1,6-2 juta rupiah untuk ukuran panjang sirip $40 \mathrm{~cm}$ per kilogram. Sedangkan harga terendah untuk ukuran panjang sirip antara $12-15 \mathrm{~cm}$ yaitu berkisar 200 sampai 400 ribu rupiah per kilogram (Dharmadi dan Fahmi, 2006). Oleh karena itu nelayan di daerah Lamongan tidak melepaskannya kembali ke alam apabila tidak sengaja tertangkap (bycatch) dengan menggunakan daftar IUCN Red List Threatened Spesies atau spesies yang terancam pada tanggal 17 Juli 2019 (Kyne et al., 2019). Hal tersebut dikarenakan Pari kekeh memiliki fekunditas rendah, namun aktifitas penangkapannya selalu meningkat (Parmanto, 2019).

Produksi perikanan Pari kekeh (Rhynchobatus sp.) menurut data Direktorat Jendral Perikanan Tangkap 2017, sejak 2005 hingga 2016 mengalami penurunan sebesar 80\% dari 28.492 ton menjadi 7.483 ton akibat penangkapan secara besar-besaran yang terus terjadi.Penangkapan Pari kekeh secara terus-menerus dalam jumlah yang banyak, akan mengakibatkan populasi Pari kekeh di habitatnya menjadi terancam. Maka pengontrolan aktivitas penangkapan perlu dilakukan. Analisis aspek biologi dapat digunakan untuk upaya pengelolaan sumberdaya perikanan yang berkelanjutan. Hasil analisa aspek biologi dapat digunakan untuk mengetahui bagaimana seharusnya ikan yang boleh ditangkap dan ikan yang harus dikembalikan ke alam dengan asumsi apabila ikan tersebut dilepas dan dibiarkan hidup maka akan menghasilkan keturunan baru untuk mempertahankan populasi ikan tersebut di alam.

\section{MATERI METODE}

Penelitian dilakukan pada tanggal 13 Oktober- 8 Desember 2019 di Pelabuhan Perikanan Nusantara (PPN) Brondong, Kab. Lamongan, Jawa Timur. Materi Penelitian berupa sampe Pari kekeh (Rhynchobatus sp.) yang didaratkan di PPN Brondong dan yang tertangkap di Perairan Timur Laut Jawa, Aspek yang diteliti meliputi hubungan panjang dan berat, distribusi ikan berdasarkan panjang, distribusi ikan berdasarkan berat, nisbah kelamin, tingkat kematangan gonad, ukuran pertama kali matang gonad dan fekunditas. Metode yang digunakan ialah metode deskriptif yaitu meneliti hubungan satu penelitian atau lebih tetapi tidak melakukan perbandingan dengan sampel penelitian yang berbeda. Sampling dilakukan dengan mengukur langsung Ikan Pari kekeh segar sebanyak 160 ekor yang tersedia di pengepul dari hasil tangkapan nelayan yang telah didaratkan di PPN Brondong Kab. Lamongan. Pengukuran panjang dan berat Pari dilakukan dengan mengukur total length dari bagian moncong ikan sampai ke pangkal batang ekor dan standard length diukur dari bagian moncong ikan sampai ke bagian ujung awal ekor (Gambar 1) dengan menggunakan meteran ketelitian $1 \mathrm{~cm}$. Pari kekeh yan telah diukur panjangnya kemudian ditimbang dengan timbangan elektronik dengan ketelitian $1 \mathrm{~kg}$. 
Cara mengidentifikasi Pari kekeh jantan dan betina menurut Kinesti dan Dewantoto (2018), dengan cara memperhatikan alat kelamin. Pari kekeh yang memilik klasper merupakan jenis pari jantan, sedangkan Pari betina tidak memilki klasper. Klasper terletak di bagian pangkal ekor.(5) Pengamatan Tingkat Kematangan Gonad (TKG), penentuan TKG dengan cara membedah ikan. Kemudian melihat ciri-ciri gonadnya secara makroskopik karena telur ikan pari memiliki ukuran yang cukup besar. Penentuan TKG disesuaikan dengan tabel klasifikasi TKG menurut (Eber dan Cowley, 2009). Disajikan pada Tabel 1.

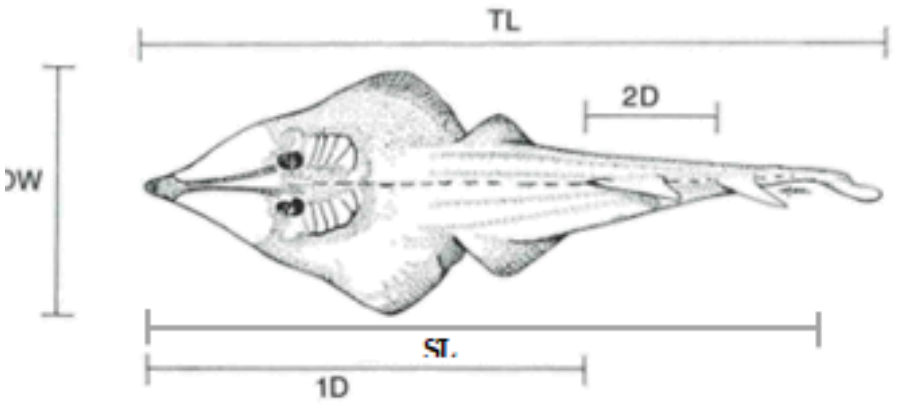

Gambar 1. Pengukuran Total Length (TL) dan Standard Length (SL) pari kekeh.

Keterangan : $\mathrm{TL}=$ Panjang total tubuh; $\mathrm{SL}=$ Panjang Standar; $\mathrm{DW}=$ Lebar Tubuh; 1D = Panjang dorsal pertama; 2D = Panjang dorsal kedua. (Sumber : Timmons, 2015)

Tabel 1. Tingkat Kematangan Gonad (TKG) Ikan Pari (Sumber: Eber dan Cowley, 2009)

\begin{tabular}{|c|c|c|}
\hline TKG & Betina & Jantan \\
\hline $\begin{array}{c}\text { I } \\
\text { Immature/belum } \\
\text { matang }\end{array}$ & $\begin{array}{l}\text { Ovarium tidak terlihat } \\
\text { serta salusan oviduk } \\
\text { terlihat dalam rahim }\end{array}$ & $\begin{array}{l}\text { Memiliki klasper yang pendek yaitu } \\
\text { tidak melampaui tepi posterior }\end{array}$ \\
\hline $\begin{array}{c}\text { II } \\
\text { Maturing/ } \\
\text { berkembang }\end{array}$ & $\begin{array}{l}\text { Ovarium terlihat jelas tetapi } \\
\text { tidak memiliki oosit matang, } \\
\text { saluran oviduk } \\
\text { berkembang }\end{array}$ & $\begin{array}{l}\text { Klasper melampaui tepi posterior } \\
\text { sirip dubur }(3-6 \mathrm{~cm}) \text {, tetapi tidak } \\
\text { memiliki klasifikasi dari unsur-unsur } \\
\text { tulang terminal }\end{array}$ \\
\hline$\stackrel{\text { III }}{\text { Mature/matang }}$ & $\begin{array}{l}\text { Terdapat oosit berwarna kuning } \\
\text { berdiameter } 1,5-2,0 \mathrm{~cm} \text {, } \\
\text { saluran oviduk yang terlihat } \\
\text { jelas, atau sudah terdapat } \\
\text { embrio yang berkembang di } \\
\text { dalam Rahim }\end{array}$ & $\begin{array}{l}\text { Panjang klasper mencapai } 6-9 \mathrm{~cm} \\
\text { melampaui tepi posterior sirip dubur } \\
\text { dan memiliki klasifikasi dari unsur- } \\
\text { unsur tulang rawan terminal }\end{array}$ \\
\hline
\end{tabular}

Analisis data yang dilakukan yaitu Perhitungan interval kelas, Data ukuran panjang dan berat dikelompokkan ke dalam kelas-kelas panjang. Penentuan Interval kelas panjang dengan metode interval teratur. Interval teratur yaitu dengan membagi data sedemikian rupa dengan interval antar data memiliki nilai selisih yang sama. Cara menentukan kelas panjang dengan interval teratur yaitu: Penentuan jumlah kelas dengan rumus Sturguess (Efendiansyah, 2018). Hubungan panjang dan berat ikan dihitung dengan menggunakan persamaan menurut Nurhayati et al. (2016).

Analisa nisbah kelamin ditentukan dengan menggunakan uji Chi-square $\left(\mathrm{X}^{2}\right)$ yang berfungsi untuk mengetahui perbandingan populasi antara ikan jantan dan betina seimbang atau tidak. Metode uji Chi-square $\left(X^{2}\right)$ yang dikemukakan oleh (Omar et al., 2015). Ukuran pertama kali matang gonad dihitung menggunakan kriteria yaitu kelompok ikan yang belum matang gonad (TKG I, II) dan ikan matang gonad (TKG III), ukuran panjang yang digunakan adalah Total Length (TL), kemudian ukuran pertma kali matang gonad dianalisis dengan persamaan berdasarkan metode Spearman - Karber (Efendiansyah, 2018). Fekunditas dihitung secara langsung dan 
dikelompokkan berdasarkan kisaran kelas panjang total. Kemudian fekunditas dihubungkan dengan panjang total tubuh ikan dengan menggunakan analisis regresi (Effendie, 2002).

\section{HASIL DAN PEMBAHASAN}

Menurut Sunarni (2017), analisa hubungan panjang berat dapat digunakan untuk menduga bobot dan panjang ikan sehingga dapat diketahui sifat atau pola pertumbuhan ikan tersebut. Selain itu, mengetahui hubungan panjang dan berat dapat digunakan untuk penentuan ukuran mata jaring yang digunakan untuk menangkap ikan.

Pengukuran panjang total dan berat Pari kekeh (Rhynchobatus sp.) dengan menggunkan 160 sampel pada 2 pengepul yang ada di PPN Brondong mendapatkan hasil perhitungan regresi hubungan antara panjang total ikan dengan berat tubuh Ikan Pari diketahui nilai $\mathrm{Y}=2,5175 \mathrm{x}-$ 9.7602 dimana nilai eksponen $b=2,5175$ dan nilai $a=(-9,7602)$, dengan nilai kepercayaan $R^{2}=$ 0,6639 atau 66,4 \% (Gambar 2).

Hasil perhitungan regresi menunjukkan nilai $b<3$, sehingga dapat disimpulkan hasil hubungan panjang dan berat menunjukkan pola pertumbuhan Pari kekeh bersifat allometrik negatif, yaitu petumbuhan panjang Pari kekeh lebih cepat dari pertumbuhan berat. Hal tersebut sesuai dengan pernyataan Nurhayati et al. (2016), yang menyatakan apabila nilai $\mathrm{n}<3$ maka ikan memiliki pola pertumbuhan allometrik negatif dan termasuk jenis ikan kurus.

Berdasarkan Gambar 2. analisis hubungan panjang berat nilai $\mathrm{R}^{2}$ sebesar 0,6639 . Nilai tersebut menunjukkan bahwa pertambahan panjang ikan pari kekeh berpengaruh terhadap pertambahan beratnya sebesar $66,4 \%$. Hasil penelitian ini berbeda apabila dibandingkan dengan hasil penelitian ikan pari spesies berbeda yaitu Himantura walga di Cilincing, Jakarta Utara yang dilakukan oleh Novariani et al. (2014), menyatakan bahwa $H$. walga memiliki pola pertumbuhan allometrik positif, maka pertambahan berat lebih cepat dibandingkan dengan panjang tubuh atau dapat dikatakan Ikan Pari $H$. walga termasuk jenis ikan gendut. Namun, apabila dibandingkan dengan penelitian Ikan Pari Neotrygon kuhlii di perairan Selat Sunda yang dilakukan oleh Boer et al. (2016), menyatakan bahwa ikan pari $N$. kuhlii memiliki pola pertumbuhan yang sama dengan ikan pari kekeh (Rhynchobatus sp.) yaitu allometrik negatif.

Perbedaan pola pertumbuhan tersebut dikarenakan adanya perbedaan pada nilai $b$ yaitu 2,5175. Menurut Efendiansyah (2018) faktor-faktor yang menyebabkan nilai b dapat berbeda ialah perbedaan spesies, faktor lingkungan, perbedaan stok ikan, perkembangan ikan, tingkat kematangan gonad, perubahan isi perut. Perbedaan jumlah dan variasi ikan yang diamati. Menurut Novariani et al. (2014), pertumbuhan ikan dapat dipengaruhi oleh faktor dalam dan luar. Diantaranya faktor dalam adalah keturunan, sedangkan faktor luar adalah makanan, suhu perairan, kualitas air, kimia perairan dan kematangan gonad. Kematangan gonad pertama kali dapat mempengaruhi pertumbuhan yaitu kecepatan pertumbuhan menjadi lebih lambat karena makanan yang dimakan tertuju pada perkembangan gonad.

Analisis distribusi Ikan Pari kekeh (Rhynchobatus sp.) sangat berkaitan dengan morfologi tubuh ikan. Hasil analisis pada penelitian ini didapatkan hasil yaitu 8 kelas interval kisaran panjang total yaitu $57-224 \mathrm{~cm}$ dengan kisaran panjang paling banyak didapatkan adalah $57-77 \mathrm{~cm}$ yang terdiri dari 28 ekor pari kekeh jantan dan 30 ekor pari kekeh betina (Gambar 3), sedangkan pada analisis distribusi ikan berdasarkan berat didapatkan 8 kelas interval dengan kisaran berat yaitu 1$24 \mathrm{~kg}$ dengan kisaran berat paling banyak didapatkan adalah 1-3 kg yang terdiri dari 30 ekor Pari kekeh jantan dan 30 ekor Pari kekeh betina.

Distribusi Ikan Pari kekeh jantan berdasarkan panjang total dan berat yaitu kisaran panjang total 57-204 cm dan kisaran berat 1-19 kg. Sedangkan Distribusi lkan Pari kekeh (Rhynchobatus sp.) betina berdasarkan panjang total dan berat yaitu kisaran panjang total $60-241 \mathrm{~cm}$ dan kisaran berat 1-24 kg. Hal tersebut menunjukaan bahwa ukuran pari kekeh (Rhynchobatus sp. betina memiliki ukuran tubuh lebih besar dibandingkan dengan pari kekeh jantan.

Pada penelitian terhadap spesies pari yang berbeda yaitu Himantura walga yang dilakukan oleh Novariani et al. (2014). Mendapatkan hasil yang sama dengan sampel Pari kekeh pada penelitian ini, yaitu Pari H.walga memiliki ukuran tubuh cenderung lebih besar dibandingkan dengan Pari H.walga jantan yaitu memiliki ukuran panjang tubuh berkisar 107-243 m untuk Pari kekeh betina dari 127-230 mm untuk Pari kekeh jantan. Haisl tersebut sesuai dengan pernyataan 
Sudarso (2007), bahwa ikan pari betina dapat tumbuh lebih besar dari jantan. Distribusi panjang dan berat Ikan Pari kekeh penyebarannya cukup merata. Hal tersebut dapat dilihat dari persebaran panjang dan berat pada setiap kelas kisaran panjang total dan kelas kisaran yang merata. Hasil distribusi Ikan Pari kekeh berdasarkan panjang dan berat pada penelitian ini yaitu panjang paling besar dan berat paling besar memiliki jumlah pari yang lebih sedikit, hal tersebut dapat dilihat dari grafik histogram yang bentuknya cenderung menurun (Gambar 3 dan Gambar 4).

Berdasarkan hasil tersebut dapat dikatakan bahwa Ikan Pari kekeh yang paling banyak didaratkan di PPN Brondong berukuran kecil-kecil. Hasil nisbah kelamin berdasarkan hasil pengamatan yang diilakukan terhadap 160 sampel Ikan Pari kekeh (Rhynchobatus sp.) diperoleh Pari kekeh jantan sebanyak 75 ekor dengan persentase 44\% dan Pari kekeh betina sebanyak 85 ekor dengan persentase 56\%. Dapat disimpulakan nisbah kelamin Pari kekeh yaitu 1:1,13. menunjukkan bahwa TKG I sudah dapat ditemukan pada kisaran panjang 60-86 cm (Gambar 8). Hasil uji Chi-square yang dilakukan menunjukan hasil $X^{2}$ hitung 0,625 dan $X^{2}$ tabel 3,975 Berdasarkan hasil tersebut menunjukkan bahwa hasil $X^{2}$ hitung $<X^{2}$ tabel atau dapat diartikan rasio kelamin Pari kekeh jantan dan betina tidak berbeda nyata atau nisbah kelamin Pari kekeh adalah seimbang. Menurut Cahmi et al. (1998), dalam populasi pari atau hiu, apabila jumlah jantan dan betina seimbang atau betina lebih banyak dapat maka populasi tersebut masih ideal untuk mempertahankan kelestaria. Menurut Candramila dan junardi (2012), ketidak seimbangan dan perbedaan jumlah hasil tangkapan dapat dipengaruhi oleh lokasi penangkapan, dan waktu

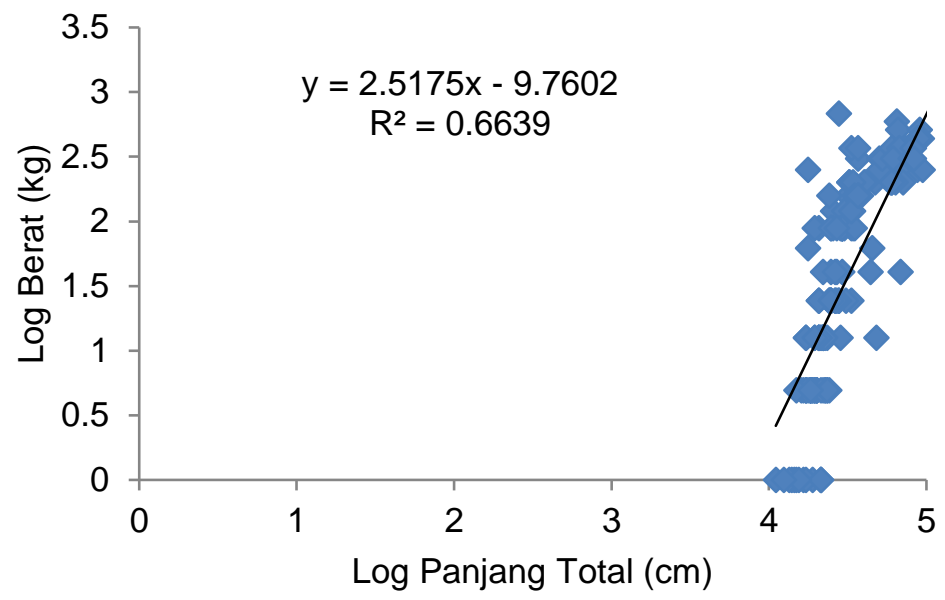

Gambar 2. Grafik Hubungan Panjang Total dan Berat Pari kekeh (Rhynchobatus sp.)

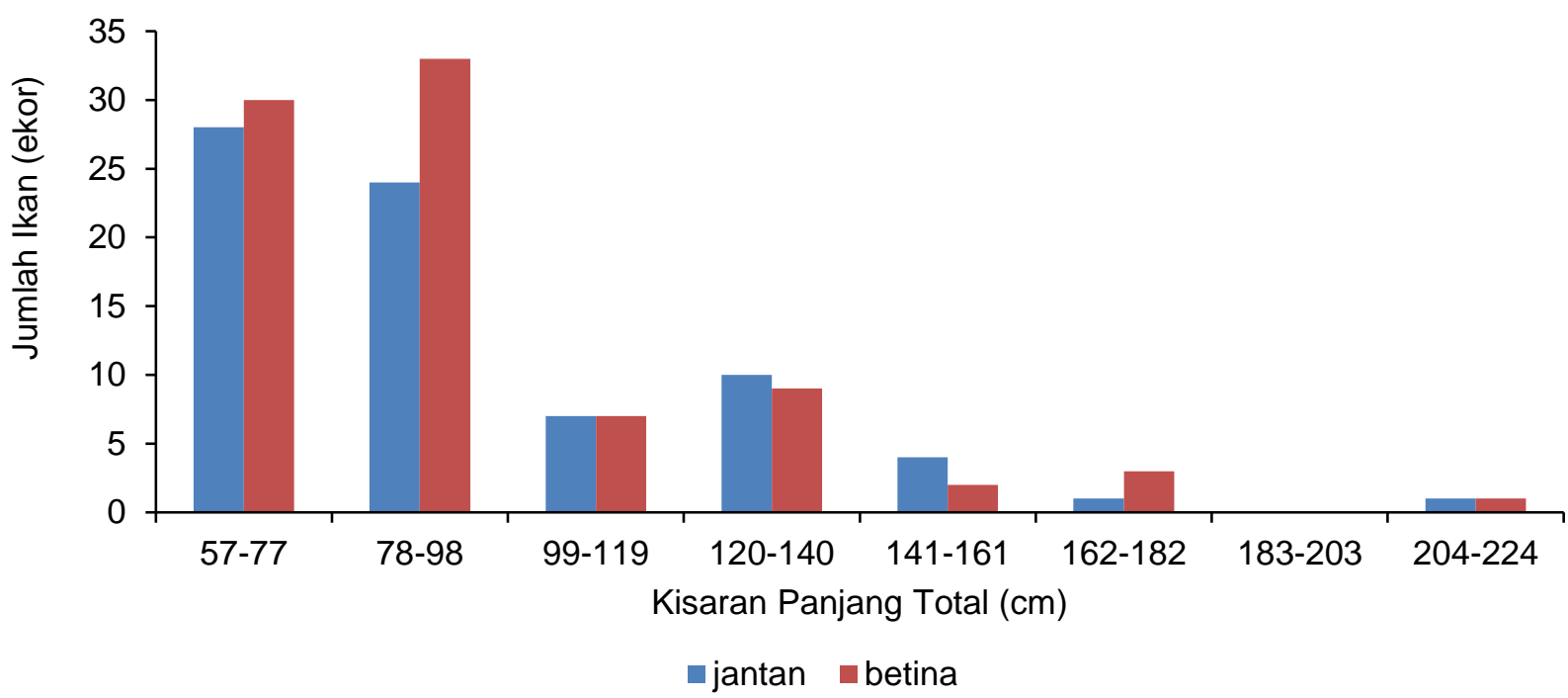

Gambar 3. Histogram Distribusi Panjang Total Ikan Pari kekeh (Rhynchobatus sp.) Periode 13 Oktober-8 Desember 2019 


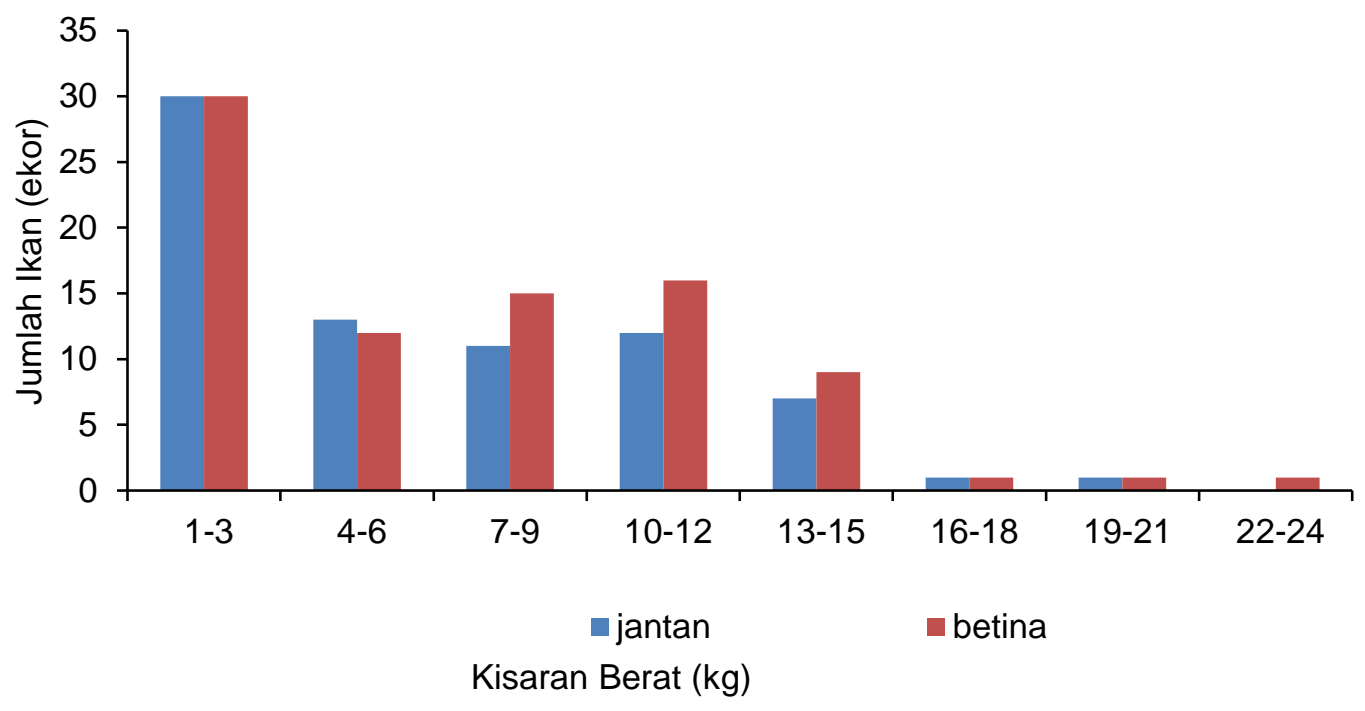

Gambar 4. Histogram Distribusi Berat Total Ikan Pari kekeh (Rhynchobatus sp.) Periode 13 Oktober-8 Desember 2019.

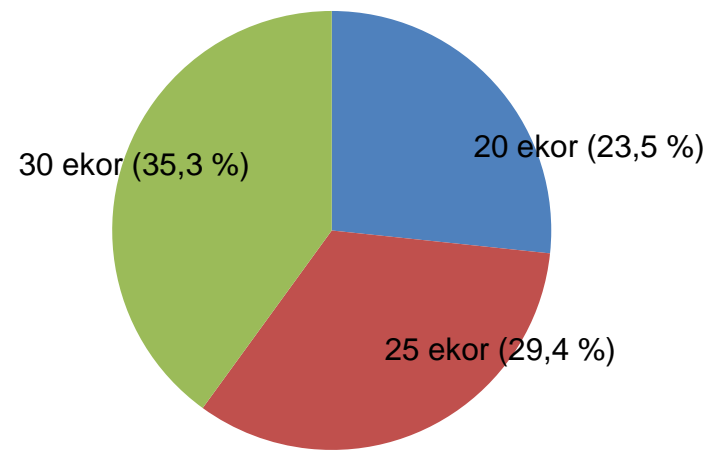

TKG I $-T K G ~ I I-T K G ~ I I I$

Gambar 5. Diagram persentase TKG Ikan Pari kekeh Jantan (Rhynchobatus sp.) berdasarkan panjang

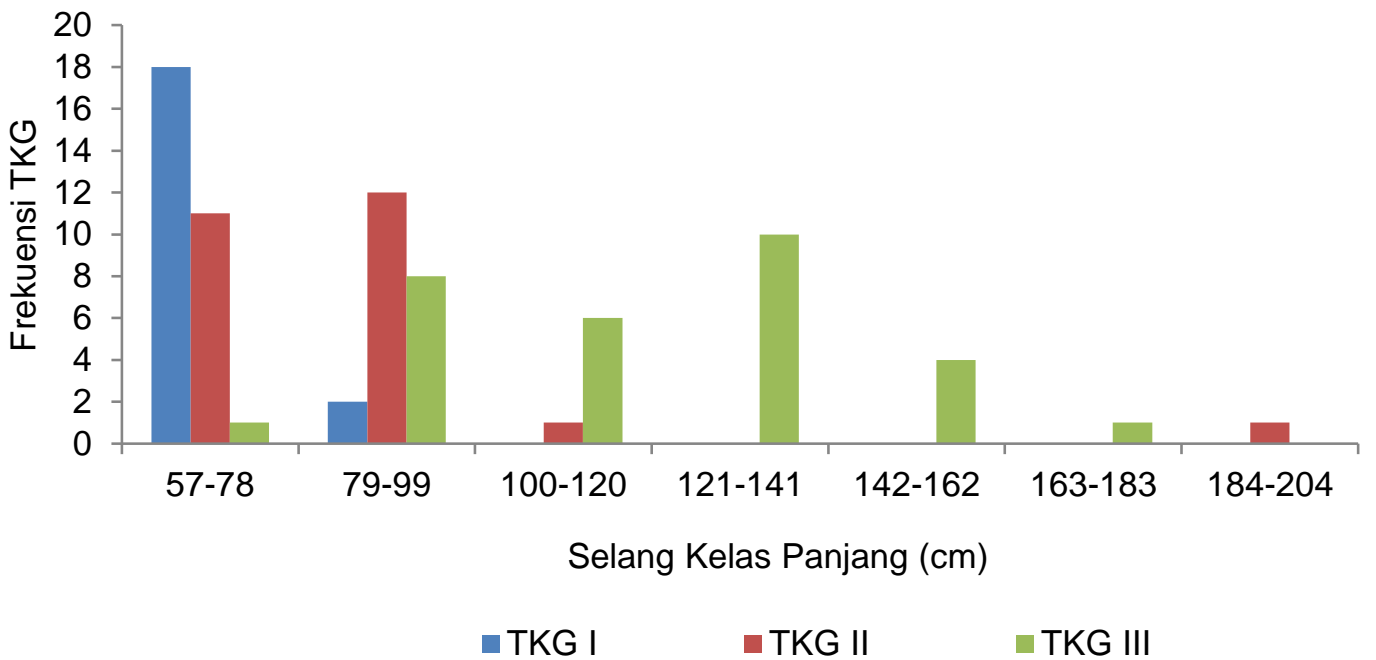

Gambar 6. Histogram Distribusi TKG Ikan Pari kekeh Jantan (Rhynchobatus sp.) Berdasarkan Panjang 


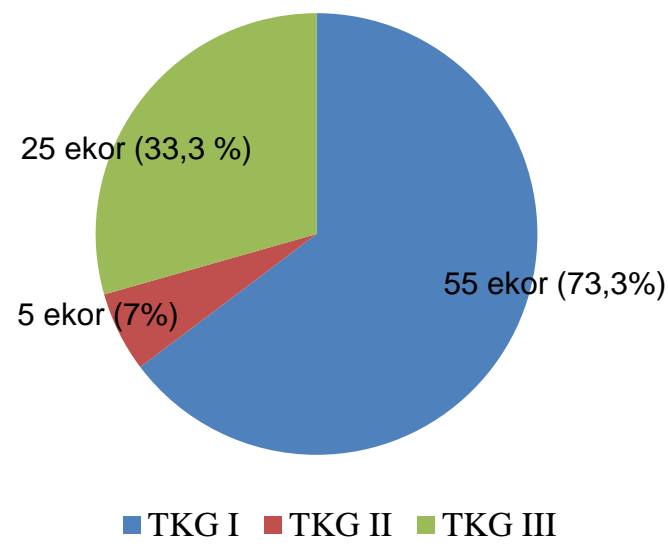

Gambar 7. Diagram persentase TKG Ikan Pari kekeh betina (Rhynchobatus sp.) berdasarkan panjang.

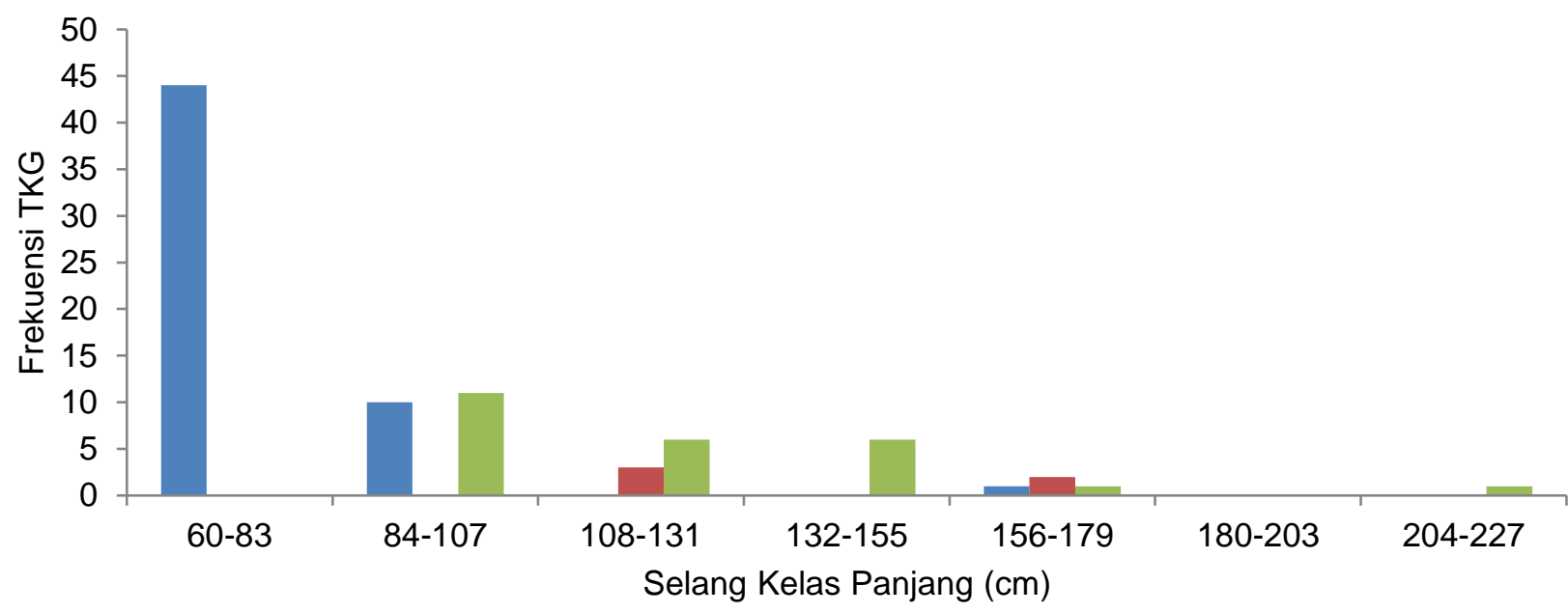

-TKG I $\quad$ TKG II $\quad$ TKG III

Gambar 8. Histogram Distribusi TKG Ikan Pari kekeh Betina (Rhynchobatus sp.) berdasarkan Panjang

penangkapan. Ikan yang hidup di dasar perairan (demersal) berpotensi tertangkap lebih sering. Selain itu, hasil tangkapan juga dipengaruhi oleh besar kecilnya armada, tipe alat tangkap dan perilaku ikan yang ditangkap.

Menurut Omar et al. (2015), nisbah kelamin yang ideal ialah 1:1, namun sering terjadi penyimpangan pada pola $1: 1$, hal tersebut dikarenakan banyak faktor seperti adanya perbedaan tingkah laku, perbedaan laju mortalitas, pertumbuhan, penyebaran ikan jantan dan betina yang tidak merata, kondisi lingkungan dan faktor penangkapan. Faktor penangkapan yang dimaksud ialah wilayah penangkapan dan alat tangkap yang digunakan. Pada penelitian ini Pari kekeh yang tertangkap merupakan Pari kekeh yang tertangkap secara bycatch di Perairan Timur Laut Jawa. dan didaratkan di PPN Brondong dengan tangkapan utama berupa Ikan Layang, Tengiri, Tongkol, Kerapu, Cucut, Bawal dan Cumi-cumi. Alat tangkap yang digunakan cantrang Alat ini termasuk tipe alat tangkap yang cukup efektif untuk menangkap ikan demersal termasuk pari kekeh.

Analisa tingkat kematangan gonad (TKG) dapat digunakan untuk mengetahui kondisi bahwa ikan akan memijah, baru memijah atau sudah memijah dalam beberapa waktu yang diketahui kemudian (Safarani dan Mashar, 2017). Pada penelitian ini, analisa tingkat kematangan gonad dilakukan dengan cara pengamatan morfologi yaitu mengamati ciri-ciri gonad dan klasper Ikan Pari kekeh Rhynchobatus sp. Hasil Tingkat Kematangan Gonad (TKG) berdasarkan analisa TKG 
didapatkan Ikan Pari kekeh (Rhynchobatus sp.) dengan tingkat kematangan gonad TKG I sampai III pada Ikan Pari kekeh jantan dan betina. Persentase TKG Ikan Pari kekeh jantan pada TKG I yaitu 23,5 \% sebanyak 20 ekor, TKG II yaitu 29,4\% sebanyak 25 ekor dan TKG III yaitu 35,3\% sebanyak 30 ekor (Gambar 5). Berdasarkan Panjang dapat dilihat dari Gambar 6 menunjukkan bahwa TKG III sudah dapat ditemukan pada kisaran panjang 78-183. Pada Ikan Pari kekeh betina memiliki nilai Persentase TKG I yaitu 73,5\% sebanyak 55 ekor, TKG II yaitu $7 \%$ sebanyak 5 ekor dan TKG III yaitu 33,3 \% sebanyak 55 ekor (Gambar 7). Sedangkan berdasarkan Panjang dapat Berdasarkan Gambar 6. dan Gambar 8. pada Ikan Pari kekeh Rhynchobatus sp. jantan memiliki jumlah tertinggi pada fase TKG III yaitu 30 ekor (35,3\%) dan terendah pada fase TKG I yaitu 20 ekor (23,5\%). Sedangkan pada Ikan Pari kekeh betina memiliki jumlah tertinggi pada fase TKG I yaitu 55 ekor (73,3\%) dan terendah pada fase TKG II yaitu 5 ekor $(6,67 \%)$. Berdasarkan hasil tersebut, dapat dikatakan bahwa Ikan Pari kekeh jantan yang tertangkap dan didaratkan di PPN Brondong 35,3\% didominasi oleh ikan Pari kekeh jantan mature (matang gonad), sedangkan Ikan Pari kekeh betina yang tertangkap dan didaratkan di PPN Brondong 73,3\% didominasi oleh Ikan Pari kekeh betina immature(belum matang gonad). Secara keseluruhan berdasarkan tabel 2.apabila jumlah total TKG II dan TKG III Ikan Pari kekeh jantan dan betina di jumlahkan maka $>50 \%$ yaitu $53 \%$ hasil tangkapan yang didaratkan di PPN Brondong didominasi oleh pari kekeh yang telah matang gonad.

Analisa ukuran pertama kali matang gonad pada penelitian ini dianalisis dengan menggunakan metode Spearman Karber. Berdasarkan hasil analisis ukuran pertama kali matang gonad Pari kekeh (Rhynchobatus sp.) didapatkan ukuran pertama kali matang gonad untuk Pari kekeh jantan pada kisaran panjang 48,97-49,16 cm dan untuk pari kekeh betina pada kisaran panjang 95,29-98,60 cm.

Berdasarkan hasil analisis tersebut dapat dilihat bahwa ikan jantan mulai matang gonad pada ukuran lebih kecil dibanding ikan betina, yang berarti bahwa Ikan Pari kekeh jantan lebih cepat matang gonad daripada ikan pari kekeh betina. Pada penelitian menggunakan sampel Ikan Pari Blentik N. kuhlii di Perairan Selat Sunda yang dilakukan oleh Boer et al. (2016), juga mendapatkan hasil yang sama yaitu Ikan Pari $N$. kuhlii jantan memiliki ukuran badan lebih kecil saat matang gonad dibandingkan dengan Ikan Pari $N$. kuhlii betina, yaitu kisaran panjag total tubuh 550-760 mm untuk jantan dan 550-799 mm untuk betina. Hal tersebut sesuai dengan penelitian Jayadi (2011) yang menyatakan Ikan Pari jantan ukurannya lebih kecil pada saat matang gonad dibanding ikan betina, yaitu 392-395mm pada ikan jantan dan 500-505 mm pada ikan betina. Hal tersebut dikarenakan Ikan Pari betina memerlukan ukuran porsi tubuh lebih besar pada saat matang gonad karena ukuran diameter telur ikan pari yang besar, sedangkan ikan pari jantan hanya mengikuti panjang klasper sehingga tidak memerlukan ukuran porsi tubuh lebih besar pada saat matang gonad.

Menurut Abubakar et al. (2015), perbedaan ukuran matang gonad Ikan Pari disebabkan oleh ketersedian bahan makanan di lingkungan tersebut. Ketersedian makanan adalah salah satu hal yang berpengaruh terhadap laju petumbuhan ikan, reproduksi dan dinamika populasi. Menurut Effendie (2002), ukuran pertama kali matang gonad tidak sama pada setiap spesies ikan. Begitu pula dengan ikan yanag sama spesiesnya, jika tersebar pada lintang yang berbeda lebih dari lima derajat akan menyebabkan Ikan Pari kekeh mengalami perbedaan ukuran pertama kali matang gonad.

Tabel 2. Jumlah Persentase Total TKG II dan TKG III Ikan Pari kekeh (Rhynchobatus sp.)

\begin{tabular}{cccc}
\hline \multirow{2}{*}{ No } & TKG & $\% / \%$ & \\
& Rhynchobatus sp. & II & III \\
\cline { 2 - 4 } & Jantan & 25 & 30 \\
2 & Bentina & 5 & 25 \\
\hline & Jumlah & 30 & 55 \\
& Persentase total (\%) & \multicolumn{2}{c}{53} \\
\hline
\end{tabular}


Tabel 3. Fekunditas Ikan Pari kekeh (Rhynchobatus sp.) pada Berbagai Kisaran Panjang Total

\begin{tabular}{cccccccccccc}
\hline \multirow{2}{*}{ No } & $\begin{array}{c}\text { Kisaran Kelas Panjang } \\
\text { Total Pari Betina }(\mathrm{cm})\end{array}$ & 5 & 6 & 7 & 8 & 9 & 10 & 12 & 13 & 14 & 16 \\
\cline { 3 - 11 } & $60-83$ & - & - & - & - & - & - & - & - & - & - \\
2 & $84-107$ & 1 & 3 & 4 & 1 & 2 & - & - & - & - & - \\
3 & $108-131$ & - & - & 1 & - & - & 4 & 2 & 1 & 1 & - \\
4 & $132-155$ & - & - & - & - & - & 2 & - & 3 & - & 1 \\
5 & $156-179$ & - & - & - & - & - & 1 & - & 2 & - & 1 \\
6 & $180-203$ & - & - & - & - & - & - & - & - & - & - \\
7 & $204-227$ & - & - & - & - & 1 & - & - & - & - & - \\
\hline
\end{tabular}

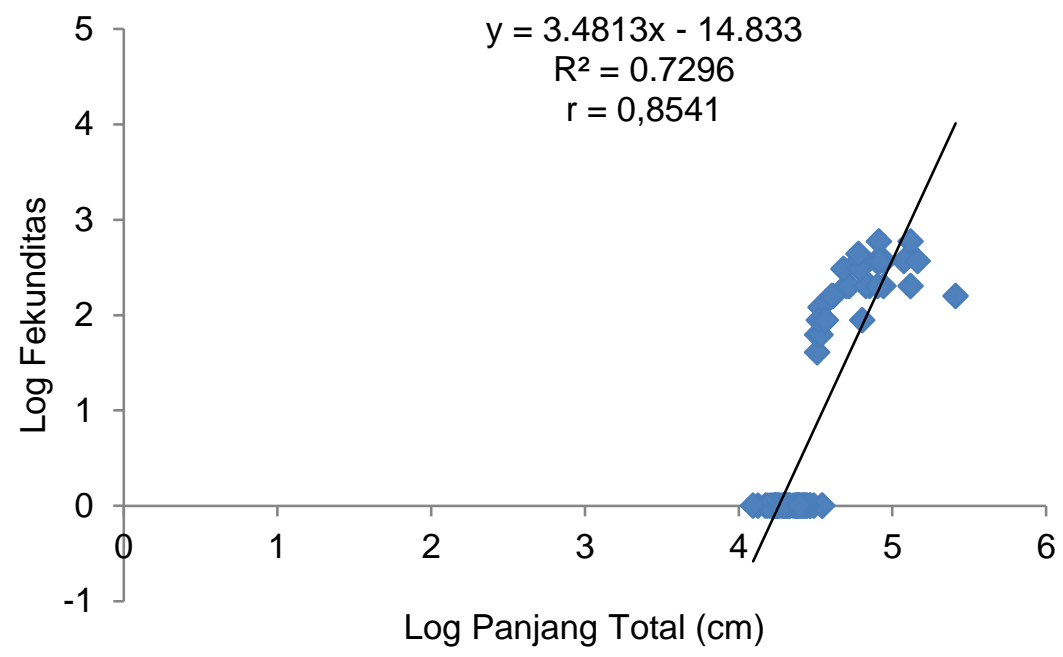

Gambar 9. Hubungan antara Fekunditas (Telur) dan Panjang Total (cm) Ikan Pari kekeh (Rhynchobatus sp.)

Fekunditas Ikan Pari kekeh (Rhynchobatus sp.) yang didaratkan di PPN Brondonng berkisar antara 5-16 butir telur pada kisaran panjang total tubuh 86-224 cm (Tabel 3). Apabila dibandingkan dengan penelitian fekunditas yang dilakukan Jayadi (2011) terhadap Ikan Pari spesies Dasyatis kuhliidi Makassar, memiliki hasil jumlah fekunditas yang berbeda yaitu berkisar 4-9 butir pada kisaran panjang total tubuh 570-780. Hal tersebut sesuai dengan pernyataan Andy Omar (2005) dalam Harianti (2013) bahwa fekunditas pada setiap individu betina tergantung pada umur, ukuran, spesies, dan kondisi lingkungan, seperti ketersedian makanan.

Berdasarkan hasil, Ikan Pari memiliki jumlah fekunditas yang sedikit. Hal tersebut sesuai dengan pernyataan Effendie (1997) bahwa ikan vivipar dan ovovivipar biasanya memilik jumlah fekunditas yang kecil (belum tentu juga. Laporan di National geographic, bisa sampai 100 butir telurnya. Coba cari referensi lagi Jumlah telur tersebut jauh lebih rendah apabila dibandingkan dengan ikan bertulang sejati (bhony fishes) yang memiliki jumlah fekunditas mencapai ratusan hingga ribuan telur. Menurut Purushottama et al. (2018), Pari Rhynchobatus sp. merupakan ikan ovovivipar dengan nilai fekunditas ysng sedikit yaitu 1-17 butir telur dan hanya menghasilkan 2-4 ekor anak. Oleh karena itu sumber daya Ikan Pari tergolong rentan terhadap penangkapan berlebihan.

Berdasarkan Gambar 9. korelasi antara fekunditas dan panjang total Ikan Pari kekeh (Rhynchobatus sp.) mendapatkan hasil korelasi positif dengan nilai koefisien korelasi yang tinggi yaitu 0,8541 . Hal tersebut menunjukan bahwa ukuran panjang tubuh mempengaruhi jumlah fekunditas betina atau dapat disimpulkan bahwa peningkayan fekunditas Ikan Pari kekeh secara 
umum sejalan dengan peningkatan ukuran panjang. Eber dan Cowley (2009) menyatakan fekunditas Ikan Pari memiliki kolerasi positif berdasarkan panjang tubuh.

\section{KESIMPULAN}

Hasil hubungan panjang dan berat menunjukkan pola pertumbuhan Pari kekeh (Rhynchobatus sp.) bersifat allometrik negatif. Hasil nisbah kelelamin menunjukkan jumlah ikan Pari kekeh jantan dan betina tidak berbeda nyata atau seimbang. Tingkat Kematangan Gonad (TKG) Pari kekeh 53\% atau 85 ekor dari 160 ekor sampel didominasi oleh Pari kekeh yang telah matang gonad (TKG III). Ukuran petama kali matang gonad pada Pari kekeh jantan mengalami pertama kali matang gonad pada kisaran panjang 48,97 - 49,16 cm dan pada Pari kekeh betina pada kisaran panjang 95,29 - 98,60 cm. Fekunditas Pari kekeh yang didaratkan di PPN Brondong berkisar antara 5-16 butir telur pada kisaran panjang total tubuh $84-224 \mathrm{~cm}$.

\section{DAFTAR PUSTAKA}

Abubakar, S., Boer, M. \& Sulistiono. 2015. Aspek Biologi Reproduksi Ikan Pari Total (Neotrygon kuhlii) di Perairan Selat Sunda. Jurnal Ternologi Perikanan dan Kelautan. 6(2):129-138.

Boer, M., Abubakar, S. \& Sulistiono. 2016. Aspek Biologi Produksi Pari Blentik Netrygon kuhlii di Perairan Selat Sunda. Jurnal Akuakultur Indonesia. 15(2):189-197.

Candramila, W. \& Junardi. 2012. Komposisi, Keanekaragaman dan Rasio Kelamin Ikan Elasmobranchii Asal Sungai Kakap Kaliman Barat. Jurnal Biospecies. 1(2):41-46.

Dharmadi \& Fahmi. 2006. Tingkat Kematengan Kelamin dan Frekuensi Panjang Pari Gitar (Rhinobatus sp.1 dan Rhinobatus sp. 2). Bawal: Widya Riset Perikanan Tangkap, 1(1):31-35.

Efendiansyah. 2018. Hubungan Panjang Berat Ikan Keperes (Cyclocheilichtyhys apagon) di Sungai Telang Desa Bakam Kabupaten Bangka. Jurnal Sumberdaya Perairan. 12(1): 1-9.

Effendi. 2002. Biologi perikanan. Yogyakarta : Yayasan Pustaka Nusatama.

Harianti. 2013. Fekunditas dan Diamtere Telur Ikan Gabus (Channa striata Bloch, 1793) di Danau Tempe, Kabuopaten Wajo. Jurnal Saintek Perikanan. 8(2):18-24.

Huda, M., Solihin, I. \& Lubis, E. 2015. Tingkat Efisien Pemasaran Ikan Laut Segar di Pelabuhan Perikanan Nusantara Brondong. Jurnal Teknologi Perikanan dan Kelautan, 6(1):91-104.

Jayadi, M.I. 2011. Aspek Biologi Reproduksi Ikan Pari (Dasyatis kuhlii Muller \& Henle, 1841) yang Didaratkan di Tempat Pelelangan Ikan Paotere Makassar. Universitas Hasanuddin. Makassar. Hal. 21-22.

Kyne, Rigby, P.M., Dharmadi. C.L. \& Jabado, R.W. 2019. Rhynchobatus australiae, Bottlenose Wedgefish. The IUCN Red List of Theatened Species. Hal. 1-16.

Nurhayati, Fauziyah \& Bernas, S.M. 2016. Hubungan Panjang Berat dan Pola Pertumbuhan Ikan di Muara Sungai Musi Kabupaten Bayuasin Sumatera Selatan. Jurnal Maspari. 8(2):111-118.

Omar, S.B.A., Nur. M., Umar, M.T., Dahlan, M.A. \& Kune, S. 2015. Nisbah Kelamin dan Ukuran Pertama Kali Matang Gonad Ikan Enemik Pirik ( Lagusia micracanthus Bleeker, 1860) di Sungai Pattunuang, Kabupaten Maros, dan Sungai Sanrego, Kabupaten Bone, Sulawesi Selatan. Semnaskan UGM. Hal. 73-81.

Parmanto. 2019. The Sustanability Status Analysis of Pari Kembang (Dayatis kuhlii) Related to Cantrang Fishing Results with Rapfish Method in Lamnongan of East Java, Indonesia. Russian Journal of Agricultural and Socio-Economic Sciences. 5(89):148-156. Doi : 10.18551/rjoas.2019-05.18 
Purushottama, G.B., Tandel, S.S., Mhatre, V.D. \& Singh, V.V. 2018. Record of Rare Elasmobranchs and Their Biological observation from The North Eastern Arabian Sea, Off Mumbai. Indian Journal of Geo Marine Sciences. 47(8):1566-1573

Safarani, D. \& Mashar, A. 2017. Kematangan Gonad dan Potensi Reproduksi Ikan Banyar (Ratrellinger kanagurta, Cuvier 1817). Jurnal Pengelolaan Perikanan Tropis. 1(1):11-16.

Sudarso, J. 2007. Kajian Biologi Ikan Pari Batu/Mondol (Himantura gerrardi) Famili Dasyatidae yang Didaratkan di PPN Penjajab, Kecapatan Pemangkat, Kabupaten Sambas, Kalimantan Barat. Jurnal Peikanan dan Kelautan. 12(1):30-35.

Sunarni. 2017. Hubungan Panjang Bobot dan Faktor Kondisi Ikan Belanak (Mugil dussumieri) di Muara Sungai Kumbe Kabupaten Merauke. Jurnal Agricola. 7(1):136-143.

Yaskun, M. dan E.Sugiarto. 2017. Potensi Hasil Parikan Laut Terhadap Kesejahteraan Para Nelayan dan Masyarakat di Kabupaten Lamongan. Jurnal Studi Manajemen dan Bisnis. 4(1): 257-264. 